\title{
改良キャパシティスペクトル法による 配管系の簡易弾塑性地震応答解析*
}

\author{
飯島唯司*1

\section{Simplified Inelastic Seismic Response Analysis of Piping System Using Improved Capacity Spectrum Method}

\author{
Tadashi IIJIMA*2 \\ ${ }^{* 2}$ Mechanical Engineering Research Laboratory. Hitachi, Ltd., \\ 832-2 Horiguchi, Hitachinaka-shi, Ibaraki, 312-0034 Japan
}

\begin{abstract}
We applied an improved capacity spectrum method (ICSM) to a piping system with an asymmetric load-deformation relationship in a piping elbow. The capacity spectrum method can predict an inelastic response by balancing the structural capacity obtained from the load-deformation relationship with the seismic demand defined by an acceleration-displacement response spectrum. The ICSM employs ( 1 ) effective damping ratio and period that are based on a statistical methodology, and ( 2 ) practical procedures necessary to obtain a balance between the structural capacity and the seismic demand. The effective damping ratio and period are defined so as to maximize the probability that predicted response errors lie inside the -10 to $20 \%$ range. However, without taking asymmetry into consideration the displacement calculated by using the load-deformation relationship on the stiffer side was $39 \%$ larger than that of a time history analysis by a direct integral method. On the other hand, when asymmetry was taken into account, the calculated displacement was only $14 \%$ larger than that of a time history analysis. Thus, we verified that the ICSM could predict the inelastic response with errors lying within the -10 to $20 \%$ range, by taking into account the asymmetric load-deformation relationship of the piping system.
\end{abstract}

Key Words : Seismic Motion, Finite Element Method, Modal Analysis, Piping System, Capacity Spectrum Method, Response Spectrum, Inelastic Response

1.

原子力施設などの各種施設における配管系の耐震設 計において，地震時の弾塑性挙動及ひ破損限界を把握 することは耐震信頼性の向上の観点から重要であり, その弾塑性応答評価法の確立が必要となっている.

配管系の弾塑性地震応答評価のための代表的な解析 手法として，直接積分による時刻歴解析がある。これ は，時刻歷波形として定義された地震入力に対して， 時々刻々の応答を幾何学的, 材料非線形性を考慮して 評価する手法である.このため, 解析精度が高く, 詳 細な評価が可能な反面, 計算時間が非常に長くなる課 題がある.この時刻歴解析には多くの場合, 汎用解析 コード(例えば ABAQUS囚(0)が用いられる. 汎用解析コ ードの幾つかでは，配管をモデル化するための弾塑性 ビーム要素が提供されており，曲管部の幾何学的非線 形性を精度良くモデル化できるため, 材料非線形性と

* 原稿受付 2005 年 3 月 3 日

*1 正員, (株) 日立製作所機械研究所(画 312-0034 ひたちなか 市堀口 832-2)

E-mail : tadashi.iijima.ts@ hitachi.com
組合せて，時刻歴解析による配管系の弾塑性応答評価 に利用されている(2).

一方，直接積分による時刻歴解析に対して，等価線 形化法などの近似手法を用いて，より簡易的に配管系の 弾塑性地震応答を評価する手法が提案されている. 例え

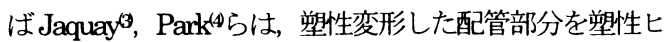
ンジに置換した解析モデルを用いて，弾塑性応答スペク トル法や等価線形化法を適用する評価法を提案している. また飯島らは，配管の設計解析で使われるフレキシビリ ティファクタを補正することで塑性変形による岡性低下 を考慮する等価線形化法を提案している.

前述の等価線形化法を用いた簡易解析手法の一つで, 非線形解析モデルによる静的弾塑性解析結果を使って簡 易応答評価を行うキャパシティスペクトル法(以下, CSMD と呼ばれる評価法が提案されているも，CSM は，コン クリート構造物などを対象に，いわゆるバフォーマンス ベースエンジニアリングに適用する地震応答評価手法と して, 近年, 注目されている手法である. パフォーマン スベースエンジニアリングは, 想定した地震荷重条件に 
対して予測される構造物の性能(パォーマンス)を考慮し た設計を行う考え方であり，地震時の構造物の応答予測 が必要となる. CSM では, 静的弾塑性解析で求めた荷重 一変位関係をもとに定義される構造物の耐力(以下, キャ バシティ)と, 入力地震波の応答スペクトルによって定義 される地震荷重条件(以下, サイスミックディマンド)の釣 合点として弾塑性応答を簡易的に評価する. Iwan, Guyader らが提案した改良 CSM(以下，ICSM)は，CSM にさらに統計的手法を導入することで，予測誤差のばら つきを考慮した簡易評価を可能にした。

本論文では, 従来, ICSMで対象とされていなかった 非対称な荷重一変位関係を有する配管系に対して, ICSM を適用寸ることを目的とした，ICSM を配管系に適用寸 る利点としては，(1)既存の汎用解析コードで作成した幾 何学的, 材料非線形性を考慮した有限要素解析モデルを 使えること，(2)統計的手法に基づいて導出した等価減衰 比，等価周期を用いて意図的に安全側の誤差を見込んだ 評価が可能なこと,が挙げられる. 一方, 課題としては, (の特定の振動モードに着目した評価になること，(b)曲管 部の幾何学的非線形性によって, 非刘称な荷重一変位関 倸になること，がある. 本論文では，上記の課題のうち 特に(b)の荷重一変位関係の非対称性に着目した評価を実 施した. ICSM で非対称性を考慮する方法を示し，その 簡易評価結果を, より高精度な応答予測が可能な直接積 分による時刻䄳解析結果と比較することで精度を検証し て，簡易応答解析手法としての適用性を検討した.

\section{2. キャパシティスペクトル法}

2.1 評価手順 図1にCSMの全体の流れを示す. CSM では,まずブッシュオーバー解析と呼ばれる静的 弾塑性解析を行い, 対象物の荷重一変位関倸(以下, プ ッシュオーバーカーブ)を評価する. 図 2 にプッシュオ 一バー解析の流れを示す.このプッシュオーバー解析 では，応答に支配的な振動モード形状の分布荷重を用 いる. そして, 評価したプッシュオーバーカーブにつ いて, 変位を刺激係数とモードベクトル成分で, 荷重 を有効質量でそれぞれ除し，キャパシティスペクトル と呼ばれる応答加速度一応答変位関係に変換する。

一方，地震荷重条件は，応答スペクトルを応答加速 度一応答変位軸で図示した加速度一変位态答スペクト ル(以下, ADRS)により定義される.この ADRSは, ディマンドスペクトルと呼ばれる. ADRSは減衰比に 依存寸るため, ディマンドスペクトルの設定で次の手 順が必要になる. 初めに, 前述のキャパシティスペク トルを等価線形化し, 塑性率 $\mu$ (降伏変位と最大変位の

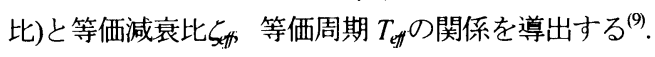

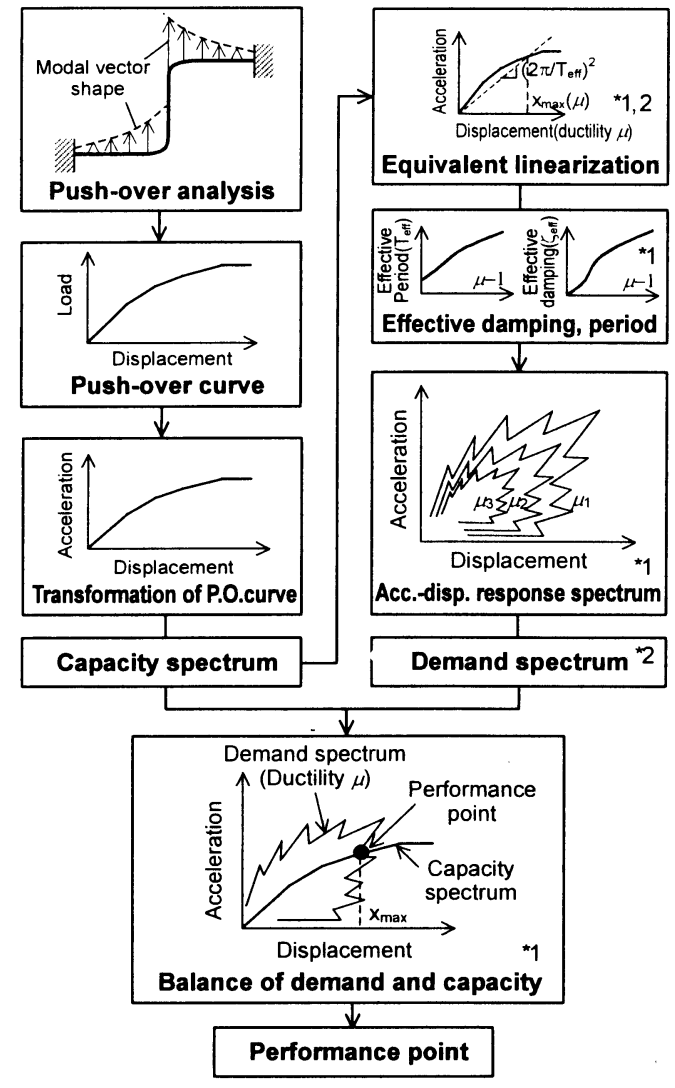

*1 Ductility $\mu$ : maximum displacement/yield displaœement *2 See references ${ }^{(6)-(8)}$ on equivalent linearization for CSM

Fig. 1 Procedure of capacity spectrum method

Eigenvalue analysis of elastic model

Calculation of i-th modal vector $\left\{q_{i j}\right\}$, participation factor $P F_{i}$, effective mass $M_{i}$

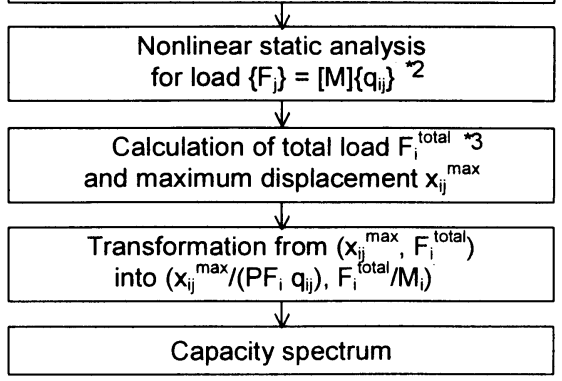

*1 $q_{i j}: j$-th comp. of $i$ th modal vector, 2 [M] : Mass matrix *3 $F_{i}^{\text {total }}=\sum_{i} F_{j}$

Fig. 2 Procedure of push-over analysis 
そして，導出した等価減衰比と塑性率川関係をもと に，塑性率の関数としてディマンドスベクトルを設定 する，従来の CSM では，等価減衰比，等価周期の導 出のために, キャバシティスペクトル上の点と原点を 結ぶ等価線形化の考え方が使われていた. その詳細は, 文献 ${ }^{(0)}$ を参照されたい.

前述したキャバシティスペクトルとディマンドスペ クトルの加速度－変位平面上での交点となる釣合点は パフォーマンスポイントと呼ばれる. このパフォーマ ンスポイントが，ディマンドスペクトルで定義される 地震荷重に対して，ブッシュオ一バ一解析で求まるキ ヤパシティを有する構造物の予測応答に相当する.

2.2 改良キャパシティスペクトル法 以下に, Iwan, Guyader らによって提案された ICSM を説明する(6).

2.2.1 等価減衰比, 等価周期 従来の CSM では, キャパシティスペクトル上の点と原点を結ぶ等価線形 化の考え方をもとに導出される等価減衰比，等価周期 を用いていた。この等価減衰比，等価周期は，減衰の 増加，岡性の低下を過大評価する場合があることが知 られている(9). そこで Iwan, Guyader らは, 幾つかの代 表的な履歴型の非線形復元力特性を有する一自由度系 を対象に，過去に計測された複数の観測地震波を入力 として, 直接積分による時刻歷解析を行った(6).そして 統計的手法に基づき，図 3 のように，時刻歴解析結果 に対する等価線形系の評価結果の誤差が-10\%から $20 \%$ の範囲内になる確率が最大となるような等価減衰比, 等価周期の導出式を提案した，乙の等価減衰比 $\zeta_{x f}$ ，等 価周期 $T_{\text {eff }}$ は, 塑性率 $\mu$ 関数であり, 次式のように表 わされる.

$\zeta_{\mathrm{eff}}-\zeta_{0}=A(\mu-1)^{2}+B(\mu-1)^{3}$ for $\mu<4.0$

$\zeta_{\text {eff }}-\zeta_{0}=C+D(\mu-1)$ for $4.0 \leq \mu \leq 6.5$

$\zeta_{\text {eff }}-\zeta_{0}=E \frac{F(\mu-1)-1}{\{F(\mu-1)\}^{2}}\left(\frac{T_{\text {eff }}}{T_{0}}\right)^{2}$ for $\mu>6.5$

$\frac{T_{e t f}}{T_{0}}-1=G(\mu-1)^{2}+H(\mu-1)^{3}$ for $\mu<4.0$

$\frac{T_{e t f}}{T_{0}}-1=I+J(\mu-1) \quad$ for $4.0 \leq \mu \leq 6.5$

$\frac{T_{\text {ctf }}}{T_{0}}-1=K\left(\sqrt{\frac{(\mu-1)}{1+L\{(\mu-1)-1\}}}-1\right)$ for $\mu>6.5$

ここでら, $T_{0}$ は, 弾性範囲の減衰比, 周期である. 式(1) 〜6)中の係数は, 二直線型などの代表的な履歷系に対 して導出されている. そのため本評価では, 静的弾塑 性解析で導出したブッシュオーバーカーブを近似的に 二直線型の履歴系に置換することで, 式(1)（6)で定義
される等価減衰比，等価周期を適用した。また，二直 線型の履歷系の各釈数は, 二次剛性比(弾性岡性に対す る塑性後の岡性の比) $0,2,5,10,20,60 \%$ に対して導出さ れている.図 4 に, 代表的に二次岡性比(図中の stiffness atio)が $10,20,60 \%$ 場合について, 塑性率 $\mu$ と等価減衰 比，等価周期の関係を示寸，本評価では，対象の二次 剛性比に対する值を線形補間によって求めた。各倸数 の值については文献(6)を参照されたい. な抏, 本評価 対象となる 10〜 60\%の二次剛性比に対して, 二次剛性 比が大きいほど減衰比が小さくなる傾向となる.

Probability $(-10 \%<$ error $<+20 \%$ )

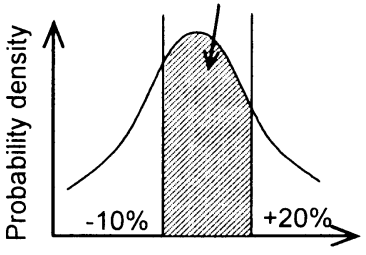

Error of maximum displacement

Fig. 3 Probability density of error

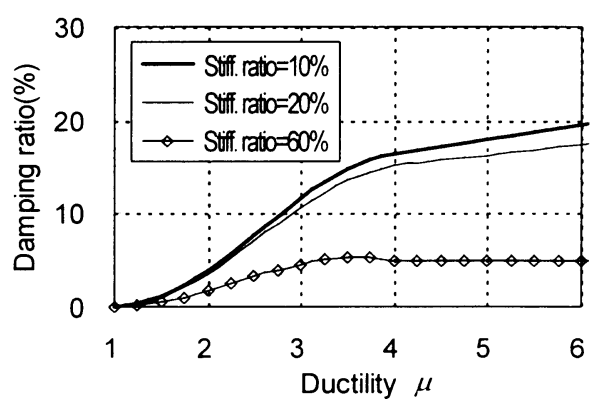

(1) Effective damping ratio

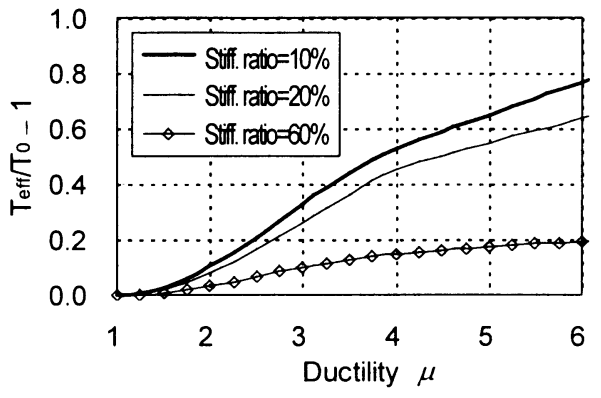

(2) Effective period

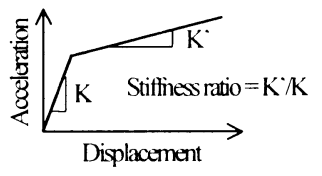

Fig. 4 Effective damping ratio and period (Ratio of second stiffness to elastic stiffness $=10,20,60 \%$ ) 


\subsection{2 パフォーマンスポイントの導出方法ＩCSM} では, 前述のように, 統計的手法に基づく等価減衰比, 等価周期を用いるため, バフォーマンスポイントの導 出で従来の CSMには無い補正が必要となる, 従来の CSMでは,キャバシティスベクル上の点と原点を結 ぶ勾配(以下，割線剛性)に基づく等価周期を使うこと を前提に，キャバシティスベクトルとディマンドスペ クトルの交点をバフォーマンスポイントとする. しか しながら ICSM では, 割線剛性と異なる等価周期 $T_{\text {ct }}$ を用いており,ディマンドスペクトル上では

$a_{\max }=\left(2 \pi / T_{\text {itf }}\right) x_{\max }^{2}$ という関係になる。 なお以降では, 式(4)

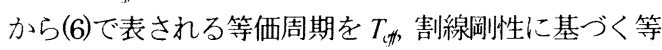
価周期を $T_{\mathrm{vx}}$ と区別して表記する。 一方，キャバシテ イスペクトル上では $a_{\max }=\left(2 \pi / T_{\mathrm{xx}}\right)^{2} x_{\max }$ という関係になっ ているため，矛盾が生じる，そこでIwan, Guyaderら は, 図5のように, キャバシティスペクトルを定義す る加速度一変位応答スペクトル ADRSについて, 加速 度 $a_{\text {max }} を\left(T_{\mathrm{xte}}\right)^{2}$ と $\left(T_{\mathrm{tgf}}\right)^{2}$ の比率で補正した加速度 $a_{\text {nax }}^{\prime}=\left(T_{\text {t fff }}\right)^{2}\left(T_{\mathrm{xx}}\right)^{2} a_{\max }$ をパフォーマンスポイントの導出に 用いることで，上記の矛盾を解決した。

さらにIwan, Guyder らは, キャバシティスペクトル とディマンドスペクトルの交点となるパフォーマンス ポイントを求めるため, 視覚的な手法を導入した. 図 6に, その概念図を示寸.この手法では, 初めに, 幾 つかの塑性率川等価減衰比に対して, 上記のように 補正した ADRS(以下, MADRS)を計算し, それぞれの MADRS と割線剛性の定義に基づく直線の交点を求め て軌跡として結ぶ。これらの交点は, 割線剛性の定義 に基づく等価周期におけるMADRS上の点に相当する. この軌跡とプッシュオーバーカーブの交点が, 導出寸 ベきパフォーマンスポイントとなる.この手法により， 応答加速度一応答変位平面上でのパフォーマンスポイ ントの導出過程を視覚的に把握寸ることが可能となる.

$2 \cdot 3$ 二直線近似の方法 Iwan, Guyader らによっ て提案された ICSM では, 式(1)〜(6)で表わされる等価 減衰比及び等価周期を用いる. それらの式中の倸数は, 二直線型の履歷系の場合, 特定の二次剛性比に対して 定義されている. 一方, 静的弾塑性解析結果をもとに 求めるキャバシティスペクトルは一般的に曲線となる.

そのため, キャパシティスペクトルを二直線近似して から適用寸る必要がある.さらに配管系の場合, 曲管 部の変形時に生じる管断面の棈円化によって, 変形方 向で荷重一变位関係が異なる特徵がある。 そのため本 評価では, 配管系の荷重一変位関係の非対称性に着目 し, 非対称性を考慮しない場合, 寸る場合の両方につ
いてICSMによる評価を試みた，以下に，それぞれに ついて二直線近似の方法を示寸.

2.3.1 非対称性を考虑しない場合 非対称性を考 慮しない場合, 正側, 負側のそれぞれの応答加速度一応答変位関係について, ヒステリシスループによる散 逸エネルギーの等価性から二直線近似を実施した。図 7 に，その概念図を示寸. 3 章の応答評価では，正側と 負側の応答加速度一応答変位関係に対して別々に二直 線近似を行い，それぞれの応答を評価した。

2.3-2 非対称性を考慮する場合 非対称性を考慮 する場合も同様, ヒステリシスループによる散逸エネ ルギーの等価性から二直線近似を実施した．ただし， 以下に示寸考え方で非対称性を考慮した. 簡単のため,

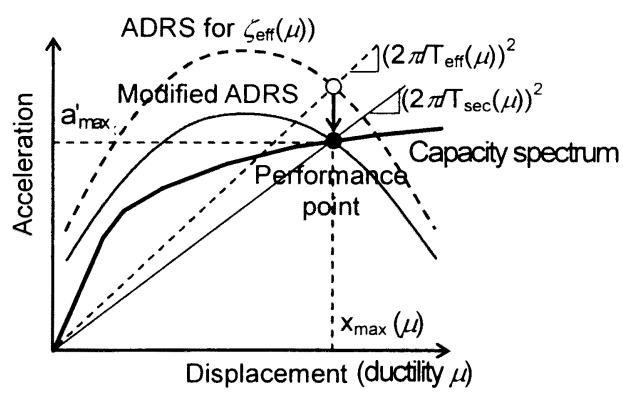

Fig. 5 Modification of ADRS

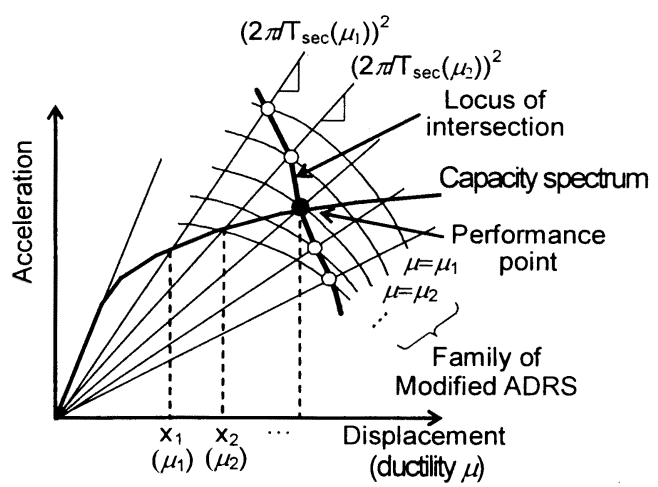

Fig. 6 Performanœ point

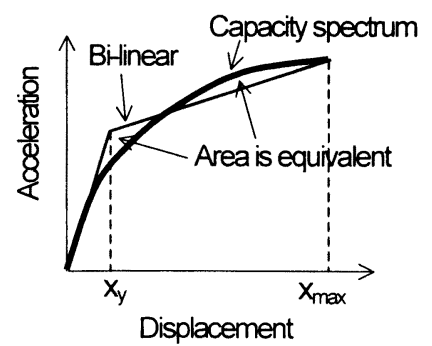

Fig. 7 Bi-linear approximation without asymmetry consideration 


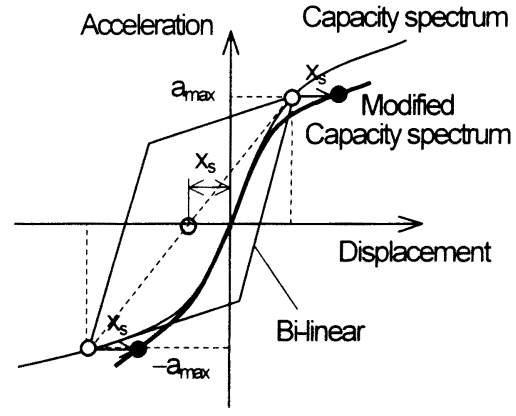

Fig. 8 Bi-linear approximation considering asymmetry and modified capacity spectrum

地震荷重が荷重制御的に配管に作用すると仮定し，地 震応答の正側と負側の最大加速度(荷重)を同一とする ことで，非対称性を考慮した二直線近似を行った。 図 8に，その概念図を示寸．このヒステリシスループの 中心は, 变位一加速度関係の非対称性のため, 原点か ら $x_{5}$ の位置にずれることになる. 本評価では，バフォ 一マンスポイントの導出において, キャバシティスペ クトルを $x_{s}$ だけ補正したカーブを用いることで, 地震 応答の変動成分のみに着目した．なお， $x_{s}$ は応答レべ ルに依存するため, キャパシティスペクトルの補正量 も応答レベルに依存する.

\section{3 . 四管系の地县疬答評価への䢗用}

\section{1 検討条件}

3.1.1 配管系モデル及び入力地震波 図 9 に, 本評 価で対象とした二次元配管系を示す。配管の外径は $216.3 \mathrm{~mm}$, 肉厚は $8.3 \mathrm{~mm}$ で, 非対称な配管ルートに 設定した. 弾性範囲の減衰比は $2.0 \%$ と仮定し, 加振方 向は図 9 の X軸方向とした.

入力条件には，卓越振動数が配管系の共振域近傍と なる人工地震波を用いた. ここで卓越振動数は, 塑性 変形で配管系の固有振動数が低下した場合に, 共振条 件により近づくように, 後述の固有振動数に対寸る比 を 0.9 とした. 図 10 に, 入力地震波の時刻歷波形及び 応答スペクトルを示す。

3.1.2 解析条件 本検討では, プッシュオーバー 解析と呼ばれる静的弹塑性解析を使う ICSM と，その 比較検証に用いる直接積分による時刻歷解析を実施し た. プッシュオーバー解析と時刻歴解析には, ABAQUS ${ }^{\circledR}($ Ver.6.4)(1)(ABAQUS'はABAQUS,Inc.の登録 商標)を用いた。 時刻歷解析では, 弾性範囲の一次及び 二次の振動モードの減衰比が $2.0 \%$ になるようにレーリ 一型減衰で設定した.
配管系の解析モデルは，曲管部の幾何学的非線形性 を考虑したエルボ要素(ABAQUS^の ELBOW31)を使つ てモデル化し，図 9 に示寸要素分割とした。材料特性 は, ヤング率 $203 \mathrm{GPa}$ ，ポアソン比 0.3 とし，二直線 近似の応力ーひずみ関倸, 線形移動硬化則を用いた。 二直線近似のパラメータには，既往研究で繰返し負荷 条件の材料圾験結果から導出された值を使用した(2).

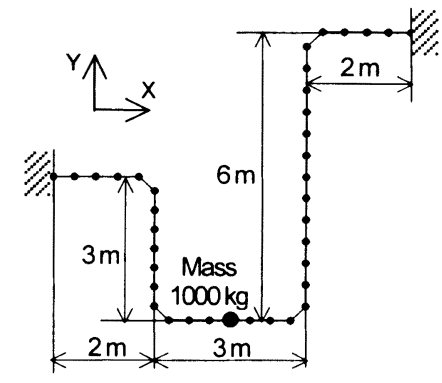

Fig. 9 Analysis model of piping system

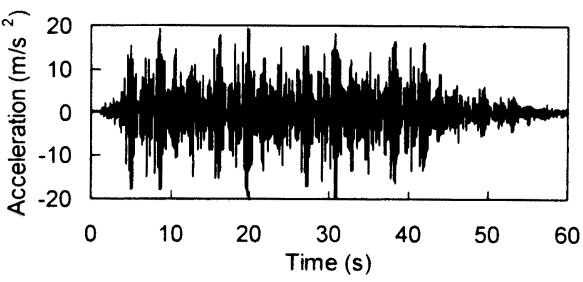

(1) Time history
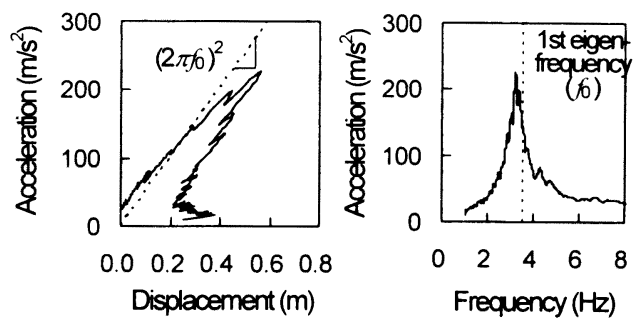

(2) Response spectrum

Fig. 10 Artificial seismic wave

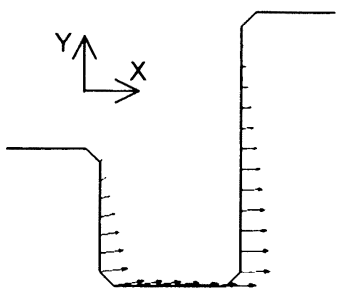

Fig. 11 Deformation form of 1st mode 
3.2 適用結果 初めに, 四9に示寸解析モデルの 固有值解析を行い，固有振動数，モードベクトルなど 在導出した。一次モードの固有振動数は $3.3 \mathrm{~Hz}$ で，図 11 に示寸ように，主に加振( $(\mathrm{X}$ 軸)方向に振れる振動乇 ードとなる. そして, 図2の手順により, 一次モード 形状の分布荷重を用いたブッシュオーバー解析を行い, キャバシティスベクトルを導出した。 な押，二次モー ドの固有振動数は $8.9 \mathrm{~Hz}$ で，主にY軸方向に振れるモ 一ドである。本検討条件では，一次の振動モードが支 配的であり，そのモード形状を分布荷重に用いた。

図 12 に，集中質量(汹 9 の Mass)の位置における変 位一荷重関倸をもとに導出したキャバシティスペクト ルの評価結果を示寸，正側と負側で非対称な特性にな っていることが分かる.このキャバシティスペクトル を用いたICSMによる簡易評価結果を，直接積分によ る時刻歴解析結果と比較した. 以下に, キャバシティ スペクトルの非效性を考慮しない場合, 寸る場合の それぞれの評価結果を示寸。

\subsection{1 非対称性を考慮しない場合 図 13 に, 正} 側及び負側について，それぞれのバフォーマンスポイ ントの導出結果を示寸. 表 1 に, ICSM と時刻歷解析 の実変位の比較結果を示寸。ここで実変位は, 加速度 一変位平面上のハ八フーマンスポイントの変位に刺激 係数とモードベクトル成分を掛けて換算した.

図 13 に示すように, 正側と負側でキャバシティス ペクトルは非対称で, より剛な正側でのパフォーマン スポイントの変位, 加速度は, 負側に比べて大きくな った. ICSMによる最大変位の評価結果は, 時刻歷解 析結果と比へ，負側の荷重一変位関係を用いた場合は 11\%のみ大きい結果だったが，正側の場合は $39 \%$ の過 大評価となった。この評価結果は, ICSM の等価減衰 比, 等価周期の設定根拠である-10\%から $20 \%$ の誤差範 曲を大きく外れた．正側の応答加速度一応答変位関係 は負側に比べて剛で，その二直線近似は二次剛性比を より大きく評価する傾向となる．正側の二直線近似に よる二次剛性比は, 同じ最大変位条件での負側の場合 に比べて, 約 37\%大きい結果であった. 2.2.1 項で述べ たように，二次剛性比を大きく設定したことで等価減 衰を過小評価し，応答を過大評価したと考えられる．

3.2.2 非対称性を考虑する場合 図 14 に, 非対 称性を考慮した場合のバフォーマンスポイントの導出 結果を示寸，この場合，正側，負側で補正後のキャパ シティスペクトルは対称となるため, 正側, 負側のバ フォーマンスポイントの変位, 加速度の絶対值は同一 となる. 表 2 に, ICSM と時刻歴解析の実変位の比較 結果を示寸.ここで実変位は, 前述の方法で換算した。
非対称性を考慮した ICSMの評価は，時刻歷解析と 比べて $14 \%$ み大きい結果となった。非対称性を考慮 することで, ICSMによる評価結果は等価隇衰比, 等 価周期の設定根拠である-10\%から 20\%の誤差範囲内と なることを確認した.

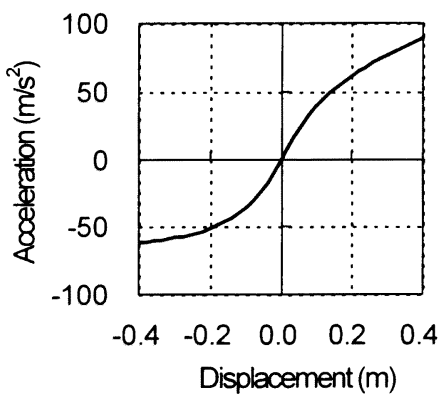

Fig. 12 Capacity spectrum

Table 1 Displacement calculated by ICSM without asymmetry consideration

\begin{tabular}{|c|c|c|}
\hline Method & Max disp. (m) & Ratio \\
\hline Time history & 0.21 & 1.00 \\
\hline ICSM (positive) & 0.29 & 1.39 \\
\hline ICSM (negative) & 0.23 & 1.11 \\
\hline
\end{tabular}

Table 2 Displacement calculated by ICSM considering asymmetry

\begin{tabular}{|c|c|c|}
\hline Method & Max disp. (m) & Ratio \\
\hline Time history & 0.21 & 1.00 \\
\hline ICSM $^{* 1}$ & 0.24 & 1.14 \\
\hline
\end{tabular}

${ }^{*} 1$ Results on positive and negative sides were the same.

\section{4. 結}

曲管部による荷重一变位関係の非対称性を有する配 管系を対象に，その非対称性に着目して，ICSMによ る簡易応答評価の適用性を検討した。簡易な二次元配 管系を対象モデルに，ICSMによる簡易評価結果を， より高精度な応答予測が可能な直接積分による時刻歴 解析結果と比較した. その結果, 非対称な荷重一変位 関係のうち剛側の関係のみを用いた場合，等価減衰を 過小評価し，変位で $39 \%$ の過大評価になった，そのた め, 荷重一変位関係の非対称性を考慮した評価を行っ た結果, 時刻歷解析に対して $14 \%$ の大きい結果とな った. したがって，簡易な二次元配管系を対象に，荷 重一変位関倸の非対称性を考慮することによって,

ICSMによる簡易評価結果の誤差を等価減衰比，等価 周期の設定根拠である-10\%から 20\%の範囲内とする評 価が可能となることを確認した。 


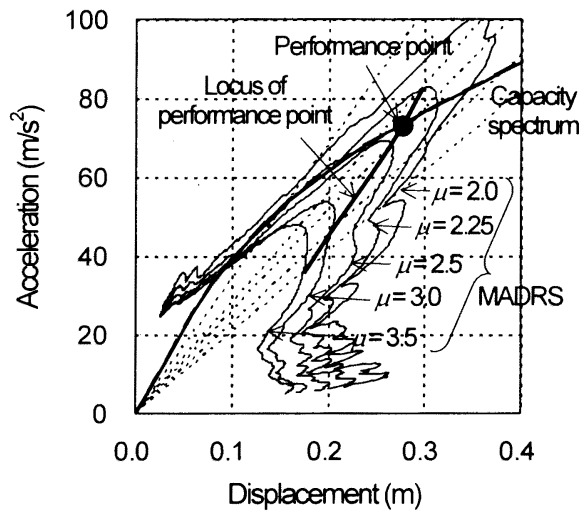

(1) Positive side

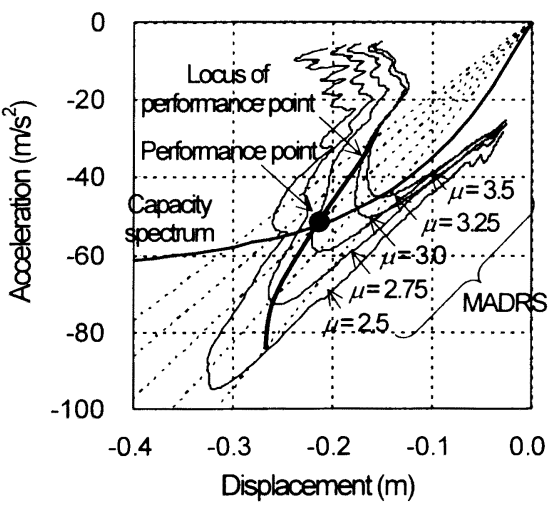

(2) Negative side

Fig. 13 Performance point without asymmetry consideration

\section{辞}

本論文の執筆に当り, ICSM の適用方法に関して有益 なご指導をいただいた California Institute of Technology の Wilfred D. Iwan 教授及びAnderew Guyader 博士に 深く謝意を表する.

\section{文献}

(1) ABAQUS, Inc., ABAQUS Analysis User's Manual, Version 6.4,(2003).

（2）財団法人原子力発電技術機構, 平成 15 年度原子 力発電施設耐震信頼性実証に関する報告書その 1 配管系終局強度, (2003), 141-155.

(3) Jaquay, K. R., Castle, W. R. and Larson, J. E., Incremental-hinge Piping Analysis Methods for Inelastic Seismic Response Prediction, Nuclear Engineering and Design, 111(1989), 311-326.

(4) Park, Y. J. and Reich, M., Non-linear 3D Piping Analysis under Stochastic Dynamic Loads, Nuclear Engineering and Design, 126(1991), 233-243.

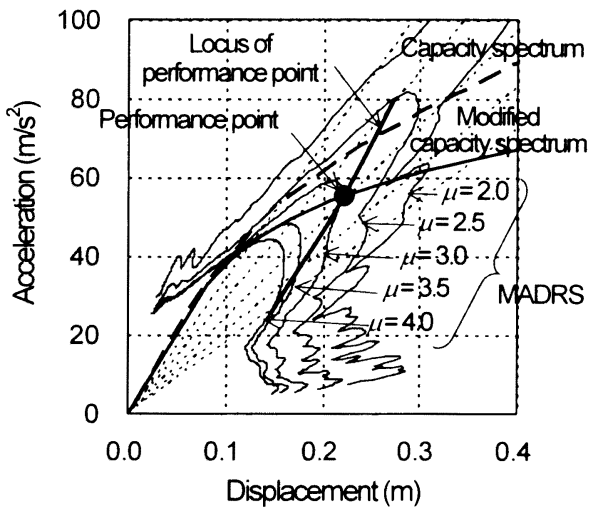

(1) Positive side

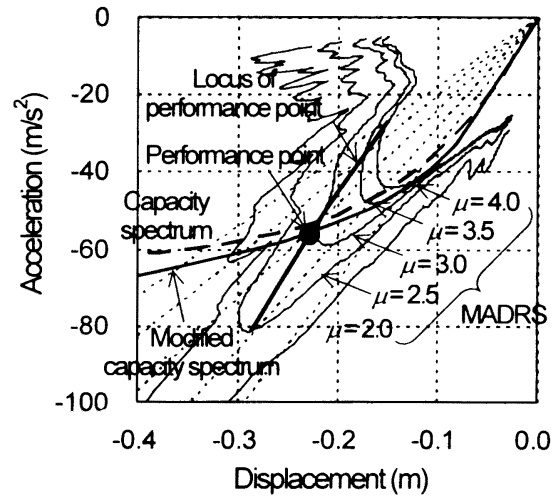

(2) Negative side

Fig. 14 Performance point considering asymmetry

（5）飯島唯司・小野悟, 等価線形化法による配管采の簡 易的な弾塑性地震応答解析, 機論, 68-673, C(2002), 26-32.

(6) Guyader, A. C., A Statistical Approach to Equivalent Linearization with Application to Performance-based Engineering, Earthquake Engineering Research Laboratory, California Institute of Technology, Report No. EERL 2004-04, (2004).

(7) Federal Emergency Management Agency, NEHRP Guidelines for the Seismic Rehabilitation of Buildings, FEMA 273, Technical report, United States Government, (1997).

(8) Applied Technology Council, ATC 40 Seismic Evaluation and Retrofit of Concrete Buildings, Technical Report, (1996).

(9) Iwan, W. D. and Gates, N. C., Estimating Earthquake Response of Simple Hysteretic Structures, Journal of the Engineering Mechanics Division, ASCE, EM3(1979), 391-405. 